\title{
Państwowa Inspekcja Pracy w świetle encykliki Laborem exercens
}

I. Problematyka inspekcji pracy jest regulowana nie tylko w przepisach poszczególnych krajów, lecz także na gruncie międzynarodowego prawa pracy. Na szczególną uwagę zasługują w tym zakresie akty prawne Międzynarodowej Organizacji Pracy (MOP), a zwłaszcza dwie ratyfikowane przez Polskę konwencje: Konwencja nr 81 z dnia 11 lipca 1947 r. dotycząca inspekcji pracy w przemyśle i handlu oraz Konwencja nr 129 z dnia 25 czerwca 1969 r. dotycząca inspekcji pracy $w$ rolnictwie ${ }^{1}$. Są one zaliczane do konwencji o charakterze generalnym, które wprowadzają ogólne standardy, dotyczące wszystkich zatrudnionych². Należy podkreślić, że obie wymienione wyżej Konwencje zaliczane są przez MOP do konwencji priorytetowych a więc takich, których ratyfikacja przez kraje członkowskie MOP jest szczególnie oczekiwana ze względu na fundamentalne znaczenie $z$ punktu widzenia funkcjonowania całego systemu międzynarodowych norm prawa pracy $^{3}$. Dodać trzeba, że normy dotyczące inspekcji oraz administracji

* Dr Dariusz MAKowskı, Katedra Prawa Pracy, Wydział Prawa i Administracji, Uniwersytet Łódzki, 90-232 Łódź, ul. Kopcińskiego 8/12.

1 Konwencje nr 81 i 129 zostały opublikowane odpowiednio w Dz. U. 1997, nr 72, poz. 450 oraz Dz. U. 1997, nr 72, poz. 452. Dnia 6 czerwca 1995 r. MOP przyjęła protokół do Konwencji nr 81 dotyczący inspekcji pracy w sektorze usług pozahandlowych, przez Polskę nieratyfikowany. O znaczeniu braku ratyfikacji przez nasz kraj protokołu z 1995 r. zob. szerzej: L. FLOREK, Zakres kontroli Państwowej Inspekcji Pracy, „Praca i Zabezpieczenie Społeczne” 2008, nr 3, s. 18-20; T. Nycz, Zakres stosowania Konwencji nr 81 MOP, cz. I, www.prawo-pracy.pl, artykuł opublikowany 18.05.2008 r. [dostęp: 15.09.2014].

2 Szerzej por.: T. WYKA, Bezpieczeństwo i ochrona zdrowia pracowników w działalności normotwórczej MOP, „Praca i Zabezpieczenie Społeczne” 2001, nr 12, s. 4, 5; eadem, Ochrona zdrowia i życia pracownika jako element treści stosunku pracy, Warszawa 2003, s. 71, 72.

3 Wyjątkowość tych Konwencji, które od 2008 r. określane są francuskim terminem Conventions de gouvernance, wynika też z faktu, że poza Konwencjami nr 81 i 129, za posiadające równie priorytetowe znaczenie MOP uznaje jeszcze Konwencję nr 122 z 1964 r. dotyczącą polityki zatrudnienia oraz Konwencję nr 144 z 1976 r. dotyczącą trójstronnych konsultacji w zakresie wprowadzania w życie międzynarodowych norm w sprawie pracy; www.ilo.org.pl. 
pracy są obecnie traktowane przez MOP jako mające wyjątkowo duże znaczenie z uwagi na globalny kryzys gospodarczy ${ }^{4}$.

Fakt ratyfikacji przez Polskę Konwencji nr 81 i 129 MOP jest także istotny z punktu widzenia hierarchii źródeł prawa. Obie Konwencje, jako ratyfikowane przez Polskę umowy międzynarodowe, stanowią część krajowego porządku prawnego i mają pierwszeństwo przed ustawą, jeżeli ustawy nie da się z nimi pogodzić (art. 91 ust. 1 i 2 Konstytucji RP5). Zasada ta dotyczy także ustawy z dnia 13 kwietnia 2007 r. o Państwowej Inspekcji Pracy (PIP) ${ }^{6}$, a więc aktu prawnego mającego podstawowe znaczenie w zakresie tej problematyki. Ustawa ta określa w szczególności kompetencje PIP, jej pozycję prawnoustrojową, organizację, a także środki działania inspekcji. Ustawowa regulacja działalności PIP wynika w jakiejś mierze z wyrażonej w Konstytucji RP zasady, w myśl której praca pozostaje pod ochroną Rzeczypospolitej Polskiej, a państwo sprawuje nadzór nad warunkami wykonywania pracy (art. 24 Konstytucji RP).

Papieska encyklika Laborem exercens nie traktuje wprost o inspekcji pracy. Mimo to lektura tego tekstu skłania do pewnych refleksji związanych z funkcjonowaniem inspekcji. Rozważania dotyczyć będą w szczególności znaczenia i roli PIP, jej zadań i funkcji, a także pojęcia pracy i osoby pracującej na gruncie encykliki oraz implikacji z tym związanych dla działalności inspekcji.

II. W pierwszej kolejności należy podjąć próbę oceny znaczenia i roli PIP w świetle encykliki Laborem exercens. Powszechnie przyjmuje się, że PIP jest wyspecjalizowanym organem nadzoru i kontroli państwa nad przestrzeganiem przepisów prawa pracy, znajdującym umocowanie dla swojej działalności w cytowanym już art. 24 Konstytucji RP . Mimo że w encyklice nie ma bezpośredniego odniesienia do PIP ani do innych organów nadzoru nad przestrzeganiem przepisów prawa pracy, to jednak rola takich organów jest pośrednio w encyklice zauważona i doceniona. Uznanie dla działalności tego typu organów kontrolonadzorczych można w szczególności odczytać z tych słów Papieża, które odnoszą się do planu powszechnego i proporcjonalnego postępu, a ściślej rzecz ujmując - do kryteriów tego postępu. Czytamy w encyklice, że „sprawdzianem postępu będzie coraz dojrzalsze uznanie celowości pracy i coraz powszechniejsze respektowanie uprawnień z nią związanych odpowiednio do godności człowieka

${ }^{4}$ Surmonter la crise: Un Pact mundial pour l'emploi, Międzynarodowe Biuro Pracy, 98 sesja Międzynarodowej Konferencji Pracy, Genewa 2009, pkt. 14, www.ilo.org. [dostęp: 16.10.2013].

${ }^{5}$ Konstytucja Rzeczypospolitej Polskiej z dnia 2.04.1997 r., Dz. U. 1997, nr 78, poz. 483, ze zm.

${ }^{6}$ Tekst jedn.: Dz. U. 2012, poz. 404, ze zm. Ustawa ta zastąpiła wcześniej obowiązującą ustawę z dnia 6 marca 1981 r. o Państwowej Inspekcji Pracy; tekst jedn.: Dz. U. 2001, nr 124, poz. 1362, ze zm.

7 PIP zasadniczo jest jednak organem pozakonstytucyjnym, nie znajduje bowiem bezpośredniego umocowania w Konstytucji RP, która w żadnym przepisie nie odnosi się wprost do PIP. Zob. T. Lıszcz, Państwowa Inspekcja Pracy - strażnik praworządności w stosunkach pracy, „Kontrola Państwowa" 2006, nr 3, s. 49; W. SkrzydŁo, Konstytucja Rzeczypospolitej Polskiej, komentarz, Warszawa 2009, s. 30; D. Makowskı, Pozycja prawna Państwowej Inspekcji Pracy, „Państwo i Prawo” 2010, nr 3, s. 46,47 . 
- podmiotu pracy"8. Jednym z kryteriów postępu jest zatem coraz powszechniejsze respektowanie uprawnień związanych z pracą odpowiednio do godności człowieka. Skoro tak, to działalność kontrolno-nadzorcza PIP, której zasadniczym celem jest zapewnienie praworządności w stosunkach pracy, tj. respektowania uprawnień człowieka pracy, jawi się jako ważny element społecznego postępu. Nie od dziś PIP tak właśnie jest postrzegana. Można więc stwierdzić, że PIP, a także inne organy nadzoru i kontroli nad przestrzeganiem przepisów prawa pracy, mają rangę organów, których skuteczność działania stanowi sprawdzian powszechnego postępu. Wydaje się, że w tych słowach Papieża PIP zyskuje niezwykle mocną legitymację do wykonywania przypisywanych jej funkcji.

Zastanawiając się nad rolą PIP w świetle nauki płynącej z encykliki Laborem exercens, nie sposób przejść obok wyrażonej w niej koncepcji rozróżniającej pracodawcę bezpośredniego i pośredniego. O ile przez pracodawcę bezpośredniego rozumie się w encyklice osobę lub instytucję, „z którą pracownik zawiera bezpośrednio umowę o pracę”, o tyle „przez pracodawcę pośredniego należy rozumieć wiele zróżnicowanych czynników, stojących poza pracodawcą bezpośrednim, i wywierających określony wpływ na to, w jaki sposób kształtuje się umowa o pracę, a w konsekwencji mniej lub bardziej sprawiedliwe stosunki w dziedzinie pracy ludzkiej" (LE 16). Wyróżnione w ten sposób pojęcie pracodawcy pośredniego „obejmuje zarówno osoby, jak też instytucje różnego typu, obejmuje również zbiorowe umowy o pracę, ustalane przez te osoby i instytucje zasady postępowania, określające cały ustrój społeczno-ekonomiczny, oraz zasady z niego wynikające". W konsekwencji wyodrębnienia pojęcia pracodawcy pośredniego Papież stwierdza, że „pojęcie pracodawcy pośredniego można stosować w wymiarze [...] przede wszystkim państwa”, ponieważ „to ono bowiem winno prowadzić właściwą politykę pracy" (LE 17)9.

Wpływ państwa na kształtowanie właściwych stosunków społecznych związanych z wykonywaniem pracy jako wyraz koncepcji pracodawcy pośredniego dokonuje się, jak się wydaje, w dwóch zasadniczo płaszczyznach: stanowienia prawa oraz stosowania prawa. Obie te płaszczyzny znajdują swoją normatywną legitymację w ustawie zasadniczej, której cytowany już wcześniej art. 24 stanowi o pozostawaniu pracy pod ochroną Rzeczypospolitej Polskiej. W płaszczyźnie stanowienia prawa państwo realizuje swoje kompetencje prawodawcze, uchwalając akty prawne w dziedzinie prawa pracy, które składają się na tzw. powszechne źródła prawa pracy ${ }^{10}$. Stanowione przez państwo przepisy prawa pracy poddawane

\footnotetext{
8 JAN PAWEk II, Laborem exercens, pkt 18, wyd. II, Wrocław 1995. Wszystkie cytaty opatrzone skrótem tytułu (LE) pochodzą z tego wydania.

${ }^{9}$ Szerzej o pojęciu pracodawcy pośredniego zob. ks. J. SIEG, Obowiązki i prawa pracodawców i pracowników, [w:] Ewangelia pracy. Encyklika Jana Pawła II "Laborem exercens” wraz z komentarzem, red. ks. J. Chmiel, ks. S. Ryłko, Kraków 1983, s. 138-141.

10 Por. art. 9 k.p. Obok powszechnych źródeł prawa pracy stanowionych przez państwo, do źródeł tego prawa ustawodawca zalicza ponadto w art. 9 k.p. tzw. specyficzne (swoiste, autonomiczne) źródła prawa pracy.
} 
są następnie kontroli i nadzorowi wykonywanemu przez organy państwowe ${ }^{11}$, wśród których najważniejszą rolę odgrywa PIP ${ }^{12}$. Nie ulega wątpliwości, że jednym z podstawowych prawnych wymiarów sfery stosowania prawa jest kontrola i nadzór w tym zakresie. Miejsce PIP jako wyspecjalizowanego organu państwowego w dziedzinie prawa pracy odnajdujemy zatem głównie w tej sferze władztwa państwowego, która dotyczy stosowania prawa. PIP - dzięki przysługującym jej kompetencjom kontrolnym i nadzorczym - stoi na straży praworządności w stosunkach pracy, zapewniając przestrzeganie obowiązujących przepisów prawa pracy. Koncepcja pracodawcy pośredniego pozwala w rezultacie określić PIP jako jedną z tych instytucji państwowych, których funkcjonowanie oddziałuje na kształtowanie stosunków społecznych w dziedzinie prawa pracy przede wszystkim w płaszczyźnie egzekwowania prawa. Należy równocześnie zauważyć, że PIP, będąc w jakiejś mierze „wpisana” w koncepcję pracodawcy pośredniego, rozwija swoje kompetencje w relacji do pracodawcy bezpośredniego ${ }^{13}$.

Chociaż kompetencje PIP zasadniczo dotyczą sfery stosowania prawa, to inspekcji tej przypisuje się także pewną rolę mającą bezpośrednie znaczenie dla procesu stanowienia prawa. Ratyfikowane przez Polskę Konwencje MOP nr 81 i 129 stanowią, że do zadań inspekcji pracy należy m.in. zwracanie uwagi właściwej władzy na uchybienia lub nadużycia nieunormowane szczegółowo w obowiązujących przepisach ${ }^{14}$. Powierzenie inspekcji takiej funkcji jest w pełni uzasadnione. Z racji przysługujących jej uprawnień kontrolno-nadzorczych PIP ma najpełniejszą wiedzę na temat stanu stosowania przepisów prawa pracy, w tym także różnych niedostatków obowiązującego ustawodawstwa. Odpowiednio spożytkowana wiedza w tym zakresie może i powinna przyczyniać się do poprawy stanu prawodawstwa. W dłuższej perspektywie zadania z tym związane mogą stanowić ważny czynnik postępu społecznego, zwłaszcza w drodze promowania nowych środków ochrony pracy. Tego rodzaju zadania przewiduje również ustawa o Państwowej Inspekcji Pracy z 2007 r. Stosownie do art. 10 ust. 1 pkt 10 tej ustawy, do zadań PIP należy opiniowanie projektów aktów prawnych z zakresu prawa pracy. Zgodnie natomiast z art. 18 ust. 1 pkt 5 ustawy, do zakresu działania Głównego

11 Poza kontrolą państwową wykonywana jest również społeczna kontrola przestrzegania prawa pracy. Kontrola ta wykonywana jest w szczególności przez społeczną inspekcję pracy na podstawie ustawy z dnia 24 czerwca 1983 r. o społecznej inspekcji pracy, Dz. U. nr 35, poz. 163, ze zm., oraz przez związki zawodowe na podstawie ustawy z dnia 23 maja1991 r. o związkach zawodowych, tekst jedn.: Dz. U. 2014, poz. 167).

12 Kompetencje kontrolne i nadzorcze PIP nie ograniczają się jednak do przepisów prawa pracy stanowionych przez państwo, ale z uwagi na obowiązywanie specyficznych źródeł prawa pracy rozciągają się także na postanowienia wynikające z tych źródeł; na ten temat por. m.in.: T. NIEDZIŃSKI, Kontrola zakładowych aktów prawnych przez inspekcję pracy, [w:] Indywidualne a zbiorowe prawo pracy, red. L. Florek, Warszawa 2007, s. 222 i n.

13 Por. art. 13 ustawy o Państwowej Inspekcji Pracy określający zakres podmiotowy jej uprawnień kontrolnych.

14 Por. art. 3 ust. 1c Konwencji nr 81 i art. 6 ust. 1c Konwencji nr 129. 
Inspektora Pracy należy opiniowanie projektów aktów prawnych dotyczących prawa pracy oraz inicjowanie prac legislacyjnych w tej dziedzinie. Ostatni z zacytowanych przepisów z jednej strony oznacza prawo, z drugiej - obowiązek wypowiadania się na temat konkretnych projektów aktów prawnych i zasięgania opinii Głównego Inspektora Pracy ${ }^{15}$.

III. Wypada z kolei zastanowić się, jak dalece zadania wykonywane przez PIP są zgodne z wizją pracy człowieka, która wyłania się z encykliki. Ze względu na to, że PIP jest organem kontroli i nadzoru nad przestrzeganiem przepisów prawa pracy, zasadne wydaje się założenie, że zadania powierzone PIP będą tym bliższe wartościom określonym w encyklice (personalistyczne ujęcie pracy i związana z tym godność osoby pracującej), im bliższe tym wartościom będzie samo prawo pracy, stanowiące przedmiot kontroli PIP. Jak się wydaje, można w związku z tym stwierdzić daleko idącą koncepcyjną bliskość podejścia do problematyki pracy na gruncie encykliki i tego, które jest przedmiotem zainteresowania prawa pracy. W pierwszej kolejności trzeba podkreślić, że w obu przypadkach dominuje podmiotowe podejście do pracy. W centrum nauki papieskiej jest człowiek i jego godność związana z wykonywaniem pracy ${ }^{16}$. Takie podejście już z założenia jest ukierunkowane na szeroko rozumianą ochronę człowieka pracy. Należy w związku z tym przypomnieć, że ochrona praw i interesów pracownika jako ekonomicznie słabszej strony stosunku pracy jest podstawową funkcją prawa pracy (funkcja ochronna). To właśnie wzgląd na celowość wzmożonej ochrony uprawnień pracowniczych legł u podstaw wyodrębnienia i rozwoju prawa pracy jako samodzielnej gałęzi prawa ${ }^{17}$. Co więcej, mimo zmieniających się uwarunkowań, wpływających na stosunki społeczne związane z pracą i oddziałujących na ochronną funkcję prawa pracy ${ }^{18}$, funkcja ta nie przestaje pełnić roli wiodącej i najpełniej oddającej właściwości prawa pracy ${ }^{19}$. O podmiotowym „zorientowaniu”

15 Tak M. Gersdorf, J. Jagielski, K. Rączka, Komentarz do ustawy o Państwowej Inspekcji Pracy, Warszawa 2008, s. 72, 73.

${ }_{16} \mathrm{Na}$ temat systemu wartości wynikających z encykliki Laborem exercens zob. szerzej T. WYKA, W poszukiwaniu aksjologii prawa pracy - o roli encykliki „Laborem exercens” Jana Pawła II, „Monitor Prawa Pracy" 2011, nr 9, s. 456-458.

17 Tej ochrony pozbawione były wcześniej osoby świadczące pracę na podstawie cywilnoprawnych umów najmu pracy (tzw. umów o świadczenie usług). O znaczeniu funkcji ochronnej w związku z genezą prawa pracy zob. np. W. Szubert, Szczególne właściwości prawa pracy, „Studia Prawno-Ekonomiczne" 1970, T. IV, s. 59 i n.; Z. SAlwa, Prawo pracy i ubezpieczeń społecznych, Warszawa 2000, s. 36; Z. NiedbaŁA, Zarys genezy prawa pracy, jego funkcje i szczególne właściwości, [w:] Prawo pracy, red. Z. Niedbała, Warszawa 2010, s. 2; L. Florek, Prawo pracy, Warszawa 2010, s. 8; B. WAGNER, Prawo pracy, Warszawa 2011, s. 24, 25.

18 Szerzej zob.: Z. HAJn, Regulacja pozycji prawnej pracownika i pracodawcy a funkcje prawa pracy, „Praca i Zabezpieczenie Społeczne” 2000, nr 10, s. 2 i n; S. SALwA, Przemiany prawa pracy początku stulecia a jego funkcja ochronna, [w:] Prawo pracy a wyzwania XXI wieku. Księga jubileuszowa Profesora Tadeusza Zielińskiego, red. M. Matey-Tyrowicz, L. Nawacki, B. Wagner, Warszawa 2002, s. $381 \mathrm{i} \mathrm{n.}$

${ }^{19}$ Z funkcją tą pozostaje w ścisłym związku semiimperatywny charakter prawny większości norm prawa pracy. 
prawa pracy może też świadczyć przyjmowane w nauce prawa pracy rozumienie słowa „praca”, stanowiącego semantyczny wyróżnik tej gałęzi prawa. Zakłada się, że chodzi właśnie o podmiotowe znaczenie tego terminu, tj. o pracę człowieka jako osoby fizycznej20.

Funkcja ochronna prawa pracy wydaje się więc stanowić najbardziej znamienny wyraz owej koncepcyjnej i ideowej bliskości podejścia do pracy człowieka przyjętej w encyklice oraz będącej wyznacznikiem prawa pracy jako gałęzi prawa. Ta bliskość jest szczególnie zauważalna w przypadku uregulowań prawa pracy, które bezpośrednio mają na celu ochronę godności człowieka pracującego. Należy stwierdzić, że takich uregulowań stale i systematycznie przybywa. Jako przykładowe można wymienić przepisy o mobbingu (art. $94^{3}$ k.p.), przepisy dotyczące równego traktowania w zatrudnieniu ${ }^{21}$, a także związane z obowiązkiem pracodawcy dotyczącym kształtowania w zakładzie pracy zasad współżycia społecznego (art. 94 pkt. 10 k.p.). Warto podkreślić, że wszystkie przepisy, ukierunkowane na ochronę godności pracowniczej, stanowią swego rodzaju rozwinięcie określonej w art. $11^{1}$ k.p. podstawowej zasady prawa pracy - obowiązku szanowania godności i innych dóbr osobistych pracownika spoczywającym na pracodawcy. Do podstawowych zasad prawa pracy należy także m.in. zasada równych praw pracowników z tytułu wykonywania takich samych obowiązków (art. $11^{2}$ k.p.) oraz niedyskryminacji pracowników (art. $11^{3}$ k.p.). Świadczy to o dużym znaczeniu, jakie ustawodawca przypisuje normom chroniącym tego rodzaju dobra. Jako podstawowe zasady prawa pracy przepisy te wyrażają bowiem podstawowe wartości tej gałęzi prawa, jaką jest prawo pracy. Tytułem uzupełnienia dodajmy, że zasady prawa pracy chroniące godność i inne dobra osobiste pracowników są równocześnie zasadami konstytucyjnymi ${ }^{22}$. Wymienione przykłady uregulowań chroniących godność pracowniczą, a przede wszystkim zasady prawa pracy obowiązujące w znaczeniu normatywnym ${ }^{23}$, są przepisami prawa pracy, których przestrzeganie - odpowiednio do art. 1 ustawy o Państwowej Inspekcji Pracy - stanowi przedmiot jej działalności kontrolno-nadzorczej.

Ochrona pracownika zajmuje centralne miejsce w regulacjach prawa pracy, co stanowi swoisty wyróżnik tego prawa w relacji do innych gałęzi prawa lub dziedzin nauki, które w pewnych zakresach również zajmują się zagadnieniem pracy.

20 Zob. np. L. Florek, T. Zieliński, Prawo pracy, Warszawa 2003, s. 2.

21 Ochronę godności pracowniczej wyrażają w szczególności przepisy o molestowaniu (art. 18 ${ }^{3 a}$ $\S 5$ pkt 2 k.p.) oraz molestowaniu seksualnym (art. $18^{3 a} \S 6$ i 7 k.p.).

22 Por. w szczególności art. 30 Konstytucji RP poświęcony zasadzie poszanowania godności człowieka, a także art. 32 stanowiący o zasadzie równego traktowania i niedyskryminacji.

23 Zasady prawa pracy w znaczeniu normatywnym są normami, które mają podstawowe znaczenie dla prawa pracy i charakteryzują się szerokim zakresem obowiązywania oraz dużym stopniem ogólności. Poza znaczeniem normatywnym w piśmiennictwie wyróżnia się ponadto zasady prawa pracy w znaczeniu postulatywnym i opisowym; szerzej zob.: Z. SAlwA, Prawo pracy...., s. 40-44; M. SkĄPSkI, Zasady prawa pracy, [w:] Prawo pracy, red. Z. Niedbała, Warszawa 2010, s. 46, 47; T. Lıszcz, Prawo pracy, Warszawa 2011, s. 75-77. 
Prawo działalności gospodarczej i nauki ekonomiczne - żeby poprzestać tylko na tych przykładach - zasadniczo eksponują jednak inne wartości związane z pracą człowieka, a przedmiotem ochrony jest tam raczej podmiot zatrudniający, nie zaś wykonawca pracy. Ze względu na funkcję ochronną prawo pracy jest więc niejako powołane do urzeczywistniania owej właściwej relacji między kapitałem i pracą, o jakiej pisał Jan Paweł II w encyklice (LE 11-15)24. PIP jako organ kontroli i nadzoru nad przestrzeganiem tych ochronnych przepisów znacząco się do tego przyczynia.

Państwowa Inspekcja Pracy w zakresie wykonywanych zadań kontrolno-nadzorczych uczestniczy zatem w procesie wdrażania tych normatywnie wyrażonych wartości, które są równocześnie tak mocno eksponowane w personalistycznym ujęciu pracy człowieka w encyklice. Uprawnione jednocześnie wydaje się postrzeganie PIP jako organu pełniącego w pewnym sensie rolę służebną (a zarazem niezbędną) w całym systemie funkcjonowania prawa pracy w relacji do zasadniczych celów i funkcji tej gałęzi prawa. Kontrolno-nadzorcze zadania PIP mają bowiem charakter poniekąd wtórny, są dopełnieniem ochronnych przepisów prawa pracy, koniecznym do zapewnienia ich stosowania (zapewnienia praworządności w stosunkach pracy).

Ochronnym regulacjom prawa pracy nie towarzyszy, niestety, satysfakcjonujący stan ich przestrzegania. Dotyczy to także tych przepisów, które mają na celu - tak bliską ujęciu pracy wyrażonemu w encyklice - właściwą ochronę godności człowieka pracy. W literaturze stwierdza się w związku z tym, że ochrona pracy nie jest skuteczna, co przejawia się w postępującym procesie dehumanizacji stosunków pracy. Głównymi przyczynami takiego stanu rzeczy są: wysoki poziom bezrobocia sprzyjający rozwojowi nielegalnego zatrudnienia i coraz bardziej rozpowszechniony typ kariery zawodowej, deprecjonujący w życiu człowieka (zwłaszcza młodego) inne wartości niż praca. Uważa się, że niezadowalający stan przestrzegania przepisów prawa pracy w dużej mierze wynika z ich wadliwości ${ }^{25}$. Słusznie jednak podkreśla się równocześnie, że nieuprawnione byłoby oczekiwanie pełnej efektywności prawa pracy ${ }^{26}$. Znamienne jest to, że za nadrzędny cel inspekcji pracy na gruncie cytowanych już Konwencji MOP nr 81 i 129 uznaje się poprawę warunków pracy (dążenie do osiągnięcia ich optymalnego stanu) i podnoszenie w ten sposób poziomu ochrony zdrowia i bezpieczeństwa fizycznego, psychicznego i socjalnego pracowników ${ }^{27}$. Celem nadrzędnym musi być zatem

24 Szerzej na ten temat zob. ks. J. SIEG, op. cit., s. 136-138.

25 Por. M. SEWERYŃSkI, Dylematy prawnej ochrony pracy, [w:] Z zagadnień prawa pracy i prawa socjalnego. Księga jubileuszowa Profesora Herberta Szurgacza, red. Z. Kubot, T. Kuczyński, Warszawa 2011 , s. $225,226$.

26 M. SEWERYŃSKI, Uwagi o efektywności prawa pracy, [w:] Księga pamiątkowa w piątą rocznicę śmierci Profesora Andrzeja Kijowskiego, red. Z. Niedbała, Warszawa 2010, s. 271.

27 J.-M. Derrien, D. Xirau, A. CAno, Systèmes d'inspection du travail et pratiques de formation des inspecteurs, 1993, www.ilo.org, s. 9 [dostęp: 16.10.2013]. 
maksymalizacja skuteczności przepisów prawa pracy oraz systematyczna poprawa warunków zatrudnienia pracowników. Znaczącym przykładem może być niedawna zmiana ustawy o Państwowej Inspekcji Pracy ${ }^{28}$, mocą której nadano nową treść art. 10 ust. 1 pkt. 7 tej ustawy. Obowiązujące do tej pory zadanie polegające na podejmowaniu działań w celu eliminowania zagrożeń w miejscu pracy zastąpiono obowiązkiem ograniczania tych zagrożeń, co świadczy o bardziej realnym podejściu do sprawy ${ }^{29}$.

IV. Szczegółowe zadania PIP30 potwierdzają zawartą w encyklice tezę, że zarówno uwarunkowania pracy, jak i sama praca, są ze swej natury zmienne. Postęp technologiczny i cywilizacyjny rodzi nowe wyzwania, ale i nowe zagrożenia, którym sprostać musi prawodawca, co nie pozostaje bez wpływu na zakres i rodzaj zadań stojących przed PIP. Wynikają one m.in. z wielorakich i wielokierunkowych zmian, jakim podlegają współcześnie stosunki pracy oraz prawo pracy w ogólności. Jak pisze Papież, „coraz to nowe bowiem powstają pytania i problemy, coraz to nowe rodzą się nadzieje, ale także obawy i zagrożenia, związane z tym podstawowym wymiarem ludzkiego bytowania, z którego życie człowieka jest zbudowane na co dzień [...]" (LE 1). Do tych wielorakich wyzwań i zagrożeń zaliczać dzisiaj należy postępujący proces starzenia się populacji zawodowo aktywnych, wysoki poziom bezrobocia osób młodych, wzmożone ruchy migracyjne, nielegalne zatrudnienie, nowe formy zatrudnienia i organizacji pracy. Na osobną uwagę zasługują nowe zagrożenia związane z postępem technicznym i technologicznym (zwłaszcza ciągle wzrastające znaczenie mikroelektroniki i robotyki), a także informatyzacją procesów pracy. Postępowi temu towarzyszą zazwyczaj zagrożenia wynikające ze stosowania nowych niebezpiecznych substancji i procesów produkcyjnych. Występujące zagrożenia w zmieniającym się środowisku pracy wymagają od inspekcji pracy bardzo dobrego przygotowania zawodowego, stąd ogromna rola, jaka przypada właściwej formacji inspektorów. Nowe zagrożenia dla zdrowia i życia pracowników wymagają ponadto większej mobilizacji działań prewencyjnych po stronie inspekcji, związanych z aktywnością edukacyjną i informacyjną ${ }^{31}$. Zagrożenia dla zdrowia pracowników są przy tym coraz liczniejsze i coraz bardziej zróżnicowane. Na pierwszy plan wysuwa się zwłaszcza problem stresu i innych zagrożeń psychospołecznych, dodatkowo potęgowanych w okresach kryzysu gospodarczego ${ }^{32}$. Znamienna jest pod tym względem

${ }^{28}$ Ustawa z dnia 9 czerwca 2011 r. o zmianie ustawy o Państwowej Inspekcji Pracy oraz niektórych innych ustaw, Dz. U. nr 142, poz. 829.

29 Por. T. M. Nycz, Zmiany w ustawie o PIP - część 1, www.prawo-pracy.pl, artykuł opublikowany 12.09.2011 r. [dostęp: 15.09.2014].

30 Por. art. 10 ustawy o Państwowej Inspekcji Pracy.

31 Szerzej zob.: W. von Richthofen, Inspekcja pracy. Przewodnik po profesji, Genewa 2002, s. 55-67, 333-348; Administration du travail et inspection du travail, Międzynarodowe Biuro Pracy, Raport V, Genewa 2011, s. 94 i n.

32 Szerzej o wpływie kryzysu gospodarczego na funkcjonowanie inspekcji pracy zob. La crise économique et sociale mundiale et son impast sur les systèmes d'inspection du travail, Międzynaro- 
prognoza Międzynarodowej Organizacji Zdrowia, według której główną przyczyną niezdolności do pracy w najbliższych latach będzie depresja ${ }^{33}$.

Wśród współczesnych wyzwań stojących przed PIP szczególnie ważny w świetle encykliki wydaje się dzisiaj ten wymiar zadań PIP, który dotyczy zjawiska migracji ludności i związanego z nią problemu legalności zatrudnienia cudzoziemców oraz dyskryminacji pracowników ze względu na narodowośćc ${ }^{34}$. $Z$ uwagi na obserwowane od wielu już lat wzmożone ruchy migracyjne, obowiązujące $w$ tym przedmiocie regulacje wyznaczają inspekcji pracy zadania, których znaczenia nie sposób przeceniać. Rola PIP jest szczególnie istotna wówczas, gdy idzie o zatrudnianie na terytorium RP obywateli z innych krajów (znaczna ich część pochodzi z krajów Europy Wschodniej). Napływające dane na ten temat mogą niepokoić. Wyłania się z nich bowiem obraz dość powszechnego zjawiska niewłaściwego traktowania pracowników cudzoziemców. Z danych PIP wynika, że w 2013 r. ponad połowa podmiotów zatrudniających takich pracowników poddanych kontroli PIP dopuściła się naruszeń prawa, przy czym nielegalne wykonywanie pracy przez cudzoziemców ujawniono w 221 podmiotach (stanowiło to blisko $12 \%$ skontrolowanych podmiotów, tj. o 1\% więcej niż w latach 2011 i $2012^{35}$. Przypomnieć wypada w związku z tym wyrażone w encyklice wezwanie i zarazem oczekiwanie, że emigracja za pracą nie będzie przyczyną gorszego traktowania przyjezdnych (LE 23). Wydaje się, że jest to dzisiaj jedno z ważniejszych wyzwań stojących przed PIP, która na gruncie obowiązującej ustawy z 2007 r. stała się organem kontroli legalności zatrudnienia, innej pracy zarobkowej oraz wykonywania pracy przez cudzoziemców ${ }^{36}$.

Podsumowując, można stwierdzić, że im więcej zagrożeń oraz im bardziej niedoskonały stan przestrzegania prawa pracy, tym znaczniejsza rola i odpowiedzialność PIP jako organu stojącego na straży stosowania tych przepisów. Chociaż warunki wykonywania pracy podlegają procesowi nieustannej ewolucji, można jednak odnieść wrażenie, że obecnie zmiany te zachodzą wyjątkowo dynamicznie, co stanowi duże wyzwanie dla PIP i innych organów kontroli przestrzegania prawa pracy.

V. Lektura encykliki Laborem exercens skłania także do refleksji na temat wynikającego z niej pojęcia pracy i osoby pracującej oraz implikacji z tym związanych

\footnotetext{
dowe Biuro Pracy, Genewa 2009 r., www.ilo.org [dostęp: 16.10.2013].

33 Podaję za: Administration du travail..., s. 96.

${ }^{34}$ Por. art. $11^{3}$ k.p. oraz art. 10 ust. 1 pkt. 4 ustawy o Państwowej Inspekcji Pracy.

35 Sprawozdanie Głównego Inspektora Pracy z działalności PIP w 2013 r., www.pip.gov.pl, s. 155 [dostęp: 15.09.2014].

${ }^{36}$ Aktualność zadań inspekcji w omawianym zakresie potwierdza także ustawa z 15.06.2012 r. o skutkach powierzania wykonywania pracy cudzoziemcom przebywającym wbrew przepisom na terytorium Rzeczypospolitej Polskiej, Dz. U. 2012, poz. 769, która w art. 23 nakłada na PIP oraz Głównego Inspektora Pracy dodatkowe obowiązki związane z wykonywaniem pracy przez cudzoziemców przebywających bez ważnego dokumentu uprawniającego do pobytu na terytorium naszego kraju. Szerzej o tej ustawie i kompetencjach inspekcji z niej wynikających zob. J. CıcHoŃ, Nielegalne zatrudnienie cudzoziemców, „Inspektor Pracy” 2013, nr 2, s. 9-12.
} 
dla działalności PIP. Gdy chodzi o pojęcie pracy w ujęciu encykliki, to jest ono bez wątpienia bardzo szerokie. Wyrasta $z$ wartości ewangelicznych, w związku z czym ma charakter uniwersalny i ponadczasowy. Jest to pojęcie interdyscyplinarne, dalece wykraczające poza pojęcie pracy przyjmowane w nauce prawa pracy. To szerokie pojęcie pracy na gruncie encykliki determinuje odpowiednio szerokie pojęcie osoby pracującej. W tym przypadku chodzi nie tylko o pracownika w rozumieniu przepisów prawa pracy ${ }^{37}$, lecz także o każdą osobę świadczącą pracę w szerokim znaczeniu przyjętym w encyklice. W tym kontekście powraca stawiane $\mathrm{w}$ nauce prawa pracy pytanie o podmiotowy zakres prawa pracy. Nie wchodząc w tym miejscu w szczegółową analizę tej problematyki, można stwierdzić, że przyjmowane na gruncie encykliki szerokie pojęcie pracy i osoby pracującej niejako wpisuje się w obserwowany już od jakiegoś czasu trend do poszerzania zakresu podmiotowego prawa pracy. Podkreślić wypada, że w tym kierunku zmierzają również rozwiązania prawne przewidywane w projekcie kodeksu pracy w ramach przygotowywanej nowej kodyfikacji prawa pracy. W projekcie przewiduje się włączenie do kodeksu zarówno przepisów dotyczących nietypowych stosunków pracy (Księga VI projektu), jak i przepisów odnoszących się do zatrudnienia niepracowniczego (Księga VII projektu) ${ }^{38}$. Zauważmy przy okazji, że tendencja do rozszerzania zakresu podmiotowego, ale także przedmiotowego, prawa pracy traktowana jest jako jedna z właściwości tej gałęzi prawa, co określane bywa mianem ekspansjonizmu lub dynamizmu rozwojowego prawa pra$\mathrm{cy}^{39}$. Z punktu widzenia działalności PIP szczególnie istotne znaczenie ma zakres obowiązujących przepisów z dziedziny bhp, wykraczający poza strony stosunku pracy i skutkujący odpowiednio poszerzonym zakresem podmiotowym uprawnień kontrolnych PIP40. To właśnie w obszarze bhp PIP posiada tradycyjnie już szczególnie mocną legitymację prawną do sprawowania funkcji kontrolno-nadzorczych, co jasno wyrażają obowiązujące dzisiaj przepisy ${ }^{41}$. Na marginesie można zauważyć, że w niektórych krajach zadania inspekcji pracy niemal wyłącznie koncentrują się na sprawach z dziedziny szeroko rozumianego bezpieczeństwa i ochrony zdrowia pracowników ${ }^{42}$.

${ }^{37}$ Por. art. 2 k.p.

${ }^{38}$ Tekst projektu dostępny na stronie Ministerstwa Pracy i Polityki Społecznej, www.mpips. gov.pl.; szerzej na ten temat zob. W. SANETRA, Niektóre sporne zagadnienia kodyfikacji prawa pracy, [w:] Problemy kodyfikacji prawa pracy. Referaty na XVI Zjazd Katedr oraz Zakładów Prawa Pracy i Ubezpieczeń Społecznych, Gdańsk 2007, s. 40 i n. Por. też M. SEWERYŃSKI, Dylematy prawnej ochrony..., s. 219, 220.

39 Por. W. Szubert, Szczególne właściwości..., s. 59.

40 Por. art. 304 k.p. i art. 10 ust. 2 i 3 ustawy o Państwowej Inspekcji Pracy.

${ }^{41}$ Por. w szczególności art. $18^{4} \S 1$ k.p. i art. 1 ustawy o Państwowej Inspekcji Pracy.

42 Model ten określa się czasami jako anglosaski, występuje bowiem przede wszystkim na Wyspach Brytyjskich oraz w krajach skandynawskich; por. Inspection du travail dans le secteur des services non commerciaux, 1994, www.ilo.org, s. 5 [dostęp: 16.10.2013]; W. von RICHTHOFEN, op. cit.; A. Omielczenko, Sankcje wobec pracodawców, „Inspektor Pracy” 2004, nr 12, s. 8. 
Szerokie pojęcie osoby pracującej na gruncie encykliki skłania do rozważenia, czy odnosi się ono - poza pracą osoby zatrudnionej w ramach stosunku pracy lub poza nim - także do osoby zatrudniającej. Innymi słowy, można się zastanawiać, czy pracującym według tej koncepcji może być tylko ten, kto nominalnie jest wykonawcą pracy, czy też może nim być także ten, kto „daje” pracę, tj. pracodawca. W analizach teksu papieskiego zwraca się uwagę na to, że człowiek będąc podmiotem pracy wykonuje różne czynności przynależące do procesu pracy, zaś źródła godności i wartości pracy ludzkiej należy szukać nie w samym rodzaju wykonywanej czynności, czyli w jej przedmiotowym wymiarze, ale w wymiarze podmiotowym ${ }^{43}$. Wydaje się wobec tego, że przyjmowane $w$ encyklice szerokie pojęcie pracy dotyczy również tej aktywności, jakiej przepisy wymagają od pracodawcy lub innej osoby zatrudniającej. Z samego już statusu osoby zatrudniającej ( $w$ tym pracodawcy) wynikają bowiem określone przepisami zobowiązania, których realizacja (np. w zakresie zapewnienia właściwych warunków pracy w dziedzinie bhp) wyczerpuje, jak można sądzić, to szerokie pojęcie pracy w rozumieniu encykliki. Pracodawca, dając pracę, równolegle sam pracę wykonuje, dbając w szczególności o zapewnienie zatrudnianym przez siebie osobom właściwych warunków pracy. Przestrzeganie przepisów prawa pracy przez pracodawcę, będąc przedmiotem działalności kontrolno-nadzorczej PIP, polega więc de facto na podjęciu przez niego szeregu wymaganych przez prawo czynności, często złożonych i absorbujących pod względem czasowym, które wyczerpują pojęcie pracy w rozumieniu encykliki. W świetle tej koncepcji pracy, jaka proponowana jest w encyklice, uprawniona wydaje się zatem ocena, że potocznie stosowane określenie „kontrola pracodawcy” można do pewnego stopnia utożsamiać z kontrolą pracy pracodawcy. Kontrola przestrzegania przez pracodawcę przepisów prawa pracy jest więc w pewnym sensie kontrolą pracy pracodawcy, mierzoną kryterium wykonania, niewykonania bądź nienależytego wykonania obowiązków podmiotu zatrudniającego względem osób zatrudnionych oraz względem państwa.

Skutkiem akceptacji tezy, że w świetle encykliki pracę wykonuje również pracodawca, musi być konstatacja, że pracującymi są obie strony stosunku pracy. Taki punkt widzenia skłania do oceny, że strony stosunku pracy łączy szczególna więź. Opiera się ona na pracy wykonywanej zarówno przez pracownika, jak i przez pracodawcę. Podobnie jak praca świadczona przez pracownika wykonywana jest na rzecz pracodawcy ${ }^{44}$, tak też praca świadczona przez pracodawcę, służąc zapewnieniu pracownikom właściwych warunków pracy, jest w jakimś sensie świadczona na ich rzecz. Ta „wspólnota pracy” stron stosunku pracy sytuuje strony tego stosunku nie w pozycji antagonistycznej, lecz raczej w relacji partnerstwa, wymagającej wzajemnej współpracy. Jak pisze bowiem Papież, „praca ma to do siebie, że przede wszystkim łączy ludzi - i na tym polega jej siła społeczna:

${ }^{43}$ Por. ks. W. GubaŁA, Praca a więź międzyludzka, [w:] Ewangelia pracy. Encyklika Jana Pawła II..., s. 126.

${ }^{44}$ Por. art. $22 \S 1$ k.p. 
siła budowania wspólnoty. W ostateczności we wspólnocie tej muszą się w jakiś sposób połączyć i ci, którzy pracują, i ci, którzy dysponują środkami produkcji lub są ich posiadaczami" (LE 20).

Uznanie, że pracodawca zatrudniając sam równocześnie wykonuje pracę, uzasadnia postulat nieco innego, bardziej zrównoważonego podejścia do funkcji wykonywanych przez PIP. Skoro bowiem w status pracodawcy wpisana jest aktywność będąca pracą, to słuszne winno być oczekiwanie poszanowania pracy wykonywanej także przez pracodawcę. Chodziłoby zatem o takie ukształtowanie funkcji PIP, które pełniej służyłyby wyeksponowaniu owej podmiotowości i godności, jaka towarzyszy każdej pracy ludzkiej, a więc również pracy pracodawcy. Wydaje się w związku z tym, że obok funkcji kontrolnej i nadzorczej, skądinąd słusznie traktowanych jako funkcje podstawowe PIP, które jednak sytuują pracodawcę w pozycji administracyjnie podporządkowanej organowi kontroli i nadzoru, odpowiedniemu dowartościowaniu winny ulec działania prewencyjne PIP. Prewencja ma bowiem to do siebie, że adresat takich działań traktowany jest w dużej mierze jak partner, któremu się ufa i wierzy się w jego wolę działania w zgodzie z obowiązującymi normami prawnymi. W ten sposób dowartościowana poniekąd zostaje również godność pracy pracodawcy. To zaufanie i wiara w wolę praworządnego działania ukierunkowuje aktywność PIP na współpracę z pracodawcą, która jest niezbędna w działalności prewencyjnej, bez niej bowiem byłoby trudno oczekiwać jakichkolwiek zakładanych skutków takiej działalności. Nie powinno wobec tego ulegać wątpliwości, że instruowanie, szkolenie oraz wykonywanie innych działań prewencyjnych może służyć kształtowaniu oczekiwanych postaw po stronie pracodawcy, traktowanego przez PIP jak partner, z którym łączy wspólny cel: przestrzeganie przepisów prawa pracy.

Stosowanie w szerokim zakresie przez inspekcję pracy działań o charakterze prewencyjnym ma swoje uzasadnienie na gruncie Konwencji MOP nr 81 i 129. W Konwencjach wykonywane przez inspekcję pracy zadania prewencyjne traktowane są na równi z wykonywanymi przez tę inspekcję zadaniami kontrolnymi ${ }^{45}$. Działania prewencyjne inspekcji pracy są też rekomendowane przez Komisję ds. Stosowania Konwencji i Zaleceń MOP. Komisja ta, nie kwestionując szczególnie ważnej roli działalności informacyjnej i poradniczej inspekcji w sferze bhp, zaleca jednak poszerzanie takiej działalności także o inne obszary i instytucje prawa pracy ${ }^{46}$. Rekomendowanym przez Komisję kierunkiem działań legislacyjnych $w$ tym zakresie jest więc przypisywanie inspekcji zadań o charakterze prewencyjnym w szerokim rzeczowo zakresie.

Zalety działań prewencyjnych inspekcji zostały już dawno zauważone także przez przedstawicieli polskiej nauki prawa pracy. W odniesieniu do działalności instrukcyjnej inspekcji w dziedzinie bhp W. Szubert już wiele lat temu stwierdzał,

45 Por. art. 3 ust. 1 Konwencji nr 81 oraz art. 6 ust. 1 Konwencji nr 129.

46 Inspection du travail..., Genewa 2006, s. 31, 33. 
że inspektor pracy występuje wówczas „nie jako organ władczy w stosunku do pracodawcy, lecz jako doradca, przychodzący z pomocą w urzeczywistnianiu zasad ochrony pracy i podsuwający $w$ tej dziedzinie najwłaściwsze rozwiązania”47. Uznając pożyteczność takiej działalności, autor podkreślał, że „pozwala ona bowiem uniknąć napięć, jakie stwarzają wszelkie interwencje o charakterze władczym [...]"48. Także w nowszej literaturze działalność prewencyjna inspekcji jest odpowiednio doceniana ${ }^{49}$.

Wprowadzenie w 2007 r. nowej i aktualnie obowiązującej ustawy o Państwowej Inspekcji Pracy stało się okazją do ożywienia dyskusji na temat znaczenia, jakie powinna mieć działalność prewencyjna PIP. Uchwaleniu nowej ustawy towarzyszyły w tej sprawie dość krytyczne oceny. Zwracano uwagę na to, że ustawa ta w niedostatecznym stopniu podkreśla prewencyjne funkcje PIP, które pozwalałyby uwzględnić potrzebę działań likwidujących przyczyny, a nie skutki naruszeń prawa ${ }^{50}$. Można z zadowoleniem stwierdzić, że wzmiankowana już wcześniej jedna z ostatnich zmian ustawy o Państwowej Inspekcji Pracy ${ }^{51}$ potwierdza dążenie do legislacyjnego wzmocnienia jej funkcji prewencyjnej. Do art. 10 ust. 1 pkt. 7 wprowadzony został nowy przepis, zgodnie z którym do zadań inspekcji należy podejmowanie działań prewencyjnych i promocyjnych, zmierzających do zapewnienia przestrzegania prawa pracy (art. 10 ust. 1 pkt. 7 lit. f). Zmiana ta wpisuje się w główne cele ustawy nowelizacyjnej, do których - zgodnie z uzasadnieniem projektu ustawy - należy m.in. wprowadzenie form oddziaływania prewencyjnego na pracodawców i przedsiębiorców ${ }^{52}$. Jak wynika z uzasadnienia projektu, działania prewencyjne i promocyjne PIP mają umożliwić zdefiniowanie oraz nadanie tej działalności właściwej roli w zapobieganiu wypadkom przy pracy i chorobom zawodowym, co jest celowe zwłaszcza w przypadku małych i średnich pracodawców. Nowy przepis ma dać PIP podstawę do podejmowania działań prewencyjnych w czasie kontroli, gdy jest ona prowadzona po raz pierwszy, nie stwierdzono bezpośrednich zagrożeń dla życia lub zdrowia, a podmiot kontrolowany jest zainteresowany realizacją uzgodnionych przedsięwzięć. Wynika stąd, że chodzi o działalność prewencyjną i promocyjną PIP, realizowaną zasadniczo w trakcie wykonywanych kontroli, co dawałoby podstawę do odróżnienia tzw. kontroli prewencyjnych (proaktywnych) od kontroli przeprowadzanych po zgłoszeniu skargi lub wniosku (reaktywnych).

47 W. SzUBERT, Ochrona pracy, Warszawa 1966, s. 155.

48 Ibidem.

49 Por. np. T. Lıszcz, Państwowa Inspekcja Pracy..., s. 55.

50 Opinia Rady Ochrony Pracy w sprawie ustawy o Państwowej Inspekcji Pracy, www.rop.sejm. gov.pl [dostęp: 16.10.2013]; M. A. Lıwo, Wokół podporządkowania Państwowej Inspekcji Pracy, „Praca i Zabezpieczenie Społeczne” 2006, nr 6, s. 34; D. Makowskı, Nowa ustawa o Państwowej Inspekcji Pracy, „Praca i Zabezpieczenie Społeczne” 2007, nr 6, s. 20.

51 Zmiana dokonana ustawą z dnia 9.06.2011 r.

52 Tekst uzasadnienia projektu ustawy dostępny na stronie www.sejm.gov.pl [dostęp: 16.10.2013]. 


\begin{abstract}
***
Język encykliki to język wartości, a właściwie hierarchii wartości w tej rzeczywistości, jaką jest praca ludzka. Można te wartości przyjąć albo odrzucić, można też je przyjąć tylko teoretycznie, ale w praktyce ich nie stosować. Podstawowym zadaniem PIP jest zapewnienie przestrzegania przepisów prawa pracy, w tym przepisów chroniących godność osób pracujących. Realizacja wartości związanych z pracą człowieka, o których Papież pisze w encyklice, powinna się bowiem dokonywać zarówno na etapie stanowienia prawa, jak i jego stosowania.
\end{abstract}

